\title{
MANAJEMEN PROGRAM HUBUNGAN SEKOLAH DAN MASYARAKAT UNTUK MENINGKATKAN KEMITRAAN
}

\author{
Inna Putri Ramadhani \\ E-mail: innaputri23@gmail.com \\ Kantor Satuan Polisi Pamong Praja Kota Malang \\ Jl. Simpang Majapahit No. 1 Malang
}

\begin{abstract}
The purpose of this research is to describe management school and community relations program in partnership at SMK Telkom Malang. The methods of the research used the qualitative approach, case study research. Data collection techniques using interview techniques, observation, and documentation. Data analysis using data reduction, data display, and verification of data. Checking the validity of the data using triangulation, member check, extension of time observation, and completeness reference. Result of management school and community relations program in partnership at SMK Telkom Malang is $80 \%$ students accepted to work, students are motivated by sharing with the alumni, and better partnership between schools and companies.
\end{abstract}

Keywords: management, school and community relationship, partnership

\begin{abstract}
Abstrak: Tujuan utama dari penelitian ini adalah untuk mendeskripsikan manajemen program hubungan sekolah dan masyarakat dalam kemitraan di SMK Telkom Malang. Metode penelitian yang digunakan yaitu pendekatan kualitatif dan jenis penelitian studi kasus. Teknik pengumpulan data menggunakan teknik wawancara, observasi, dan dokumentasi. Pengecekan keabsahan data menggunakan triangulasi, pengecekan anggota, perpanjangan waktu pengamatan, dan kecukupan referensi. Hasil dari manajemen hubungan sekolah dan masyarakat dalam kemitraan di SMK Telkom malang yaitu $80 \%$ peserta didik direkrut bekerja, peserta didik lebih termotivasi karena adanya sharing dengan alumni, dan hubungan sekolah dan dunia industri semakin baik.
\end{abstract}

Kata Kunci: manajemen, hubungan sekolah dan masyarakat, kemitraan.

Pendidikan merupakan salah satu aspek penting dalam meningkatkan mutu sumber daya manusia, untuk mencapai hal tersebut SMK Telkom Malang harus harus mampu menjalin kerja sama dengan berbagai pihak khususnya dunia usaha/ dunia industri. SMK Telkom Malang merupakan sekolah IT (Informasi dan Teknologi) Pertama di Indonesia. SMK Telkom berada di naungan Telkom Indonesia. SMK Telkom Malang dulu bernama SMK Telkom Sandhy Putra namun sekarang disebut dengan SMK Telkom Malang saja. Menurut Daryanto (2006:71-72) komunikasi dengan masyarakat di luar sekolah merupakan sesuatu kenyataan bahwa, sekolah tidak merupakan sesuatu yang berdiri sendiri terpisah dari dunia luar, melainkan berada dalam suatu sistem masyarakat yang telah tetap. Kehadiran sekolah berlandaskan kemauan baik negara dan masyarakat yang mendukungnya. Oleh karena itu orang-orang yang bekerja di sekolah mau tidak mau harus bekerja sama dengan masyarakat. Masyarakat di sini dapat berwujud orang tua murid, badan-badan, organisasi-organisasi,baik negeri maupun swasta.

Hubungan sekolah masyarakat adalah proses komunikasi antara sekolah dengan masyarakat yang bertujuan untuk mengembangkan pengertian masyarakat tentang pelaksanaan dan kebutuhan pendidikan di sekolah. Hubungan sekolah masyarakat menurut Wiyono (2010) merupakan bentuk realisasi tanggung jawab bersama antara sekolah dengan masyarakat terhadap penyelenggaraan pendidikan. Melalui humas diharapkan dapat meningkatkan kerjasama 
sekolah dengan masyarakat, terutama orangtua siswa, dalam rangka meningkatkan keberhasilan pendidikan di sekolah.

Salah satu program humas di SMK Telkom yang bekerjasama dengan dunia usaha/dunia industri adalah dengan adanya program prakerin. Pernyataan ini sesuai hasil penelitian Kusumawati (2015) bahwa sebagian besar fokus kerja humas ada di praktik kerja industri oleh karena itu sebagian besar kinerja humas yakni berinteraksi secara langsung dengan dunia usaha/dunia industri.Kerjasama antara sekolah dan dunia usaha atau dunia industri membawa manfaat yang sangat besar bagi kedua belah pihak. Pihak sekolah khususnya peserta didikpun mendapatkan manfaat yang positif. Secara garis besar manfaat yang diperoleh sekolah bekerja sama dengan dunia usaha dan dunia industri yaitu dapat mengembangkan serta meningkatkan pengajaran dan pembelajaran di sekolah. Sekolah juga dapat meningkatkan keterampilan dan mengubah sikap tingkah laku peserta didik. Bagi peserta didik sendiri, mendapatkan pengalaman bekerja, meningkatkan pengetahuan dan wawasan tentang seluk beluk dunia kerja serta dapat meningkatkan keterampilan yang dimilikinya.

Dunia usaha juga sangat berperan dalam pelaksanaan prakerin. Menurut Anwar (2006:48) peran dunia usaha dan dunia industri untuk sekolah atas program PSG adalah mengoptimalkan sumber daya manusia (SDM) yang berkualitas melalui proses belajar dan bekerja. Di sekolah peserta didik memperoleh teori yang bersifat kognitif dan akademis dan sebagian lainnya yang bersifat vokasional melalui magang di dunia kerja sehingga lebih mengenal lapangan yang sesungguhnya. Kinerja peserta didik berupa suatu perbuatan ataupun prestasi kerja diwujudkan dengan keterampilan nyata yang dilakukan oleh seorang individu sebagai subyek didik di dunia Industri, dimana harus terpenuhinya kualifikasi tugas-tugas yang diberikan kepadanya sesuai dengan standar pekerjaan yang ada.

SMK Telkom Malang banyak bekerja sama dengan dunia pendidikan maupun non pendidikan, sehingga dengan begitu lulusan dari SMK Telkom dapat langsung disalurkan untuk bekerja meskipun ada juga yang masih mau melanjutkan kuliah. Dalam hal lulusan, alumni bisa dikatakan mempunyai andil dalam mempermudah para lulusan untuk bekerja di suatu perusahaan.
Menurut Prihatin (2011:155) alumni sebagai warga yang istimewa dan memiliki ikatan batin yang kuat dengan sekolah, diharapkan peran sertanya dalam meningkatkan mutu pendidikan di sekolah dimana mereka dahulu telah merasakan layanan jasa pendidikannya.SMK Telkom memiliki program humas yang disebut dengan wikufest atau Wikusama Festival. Hubungan antara sekolah dengan para alumni dapat dipelihara lewat reuni yang bisa dimanfaatkan sekolah untuk menjaring informasi dari para alumni. Adanya track record yang baik dari para alumni di tiap perusahaan akan memberikan kepercayaan tersendiri, bahwa lulusan SMK Telkom Malang mempunyai keahlian dan etos kerja yang bagus untuk masuk ke perusahaanperusahaan tersebut. Jika ada alumni yang bekerja di salah satu perusahaan, maka sudah dijamin pada tahun berikutnya perusahaan tersebut akan merekrut lulusan dari SMK Telkom lagi. Sudah banyak lulusan yang setelah lulus langsung diterima bekerja di perusahaan-perusahaan yang menjalin hubungan dengan SMK Telkom.

Hubungan sekolah dan masyarakat merupakan hal yang sangat penting, masyarakat disini dalam artian dunia usaha atau dunia industri. Kerjasama sekolah dengan dunia usaha dan dunia industri membawa manfaat bagi beberapa pihak. Menurut Rosyidi (2011:3) kerjasama sekolah dengan dunia usaha dan dunia industri harus membawa manfaat kepada pihak sekolah, peserta didik dan industri atau perusahaan. Bagi sekolah mengetahui informasi tentang dunia kerja yang relevan dengan program studi yang ada di sekolah, bagi peserta didik meningkatan keterampilan dan pengalaman bekerja sebagai karyawan dan bagi dunia usaha/dunia industri sebagai promosi perusahaan. Daryanto (2006:7172) menyatakan komunikasi dengan masyarakat di luar sekolah merupakan sesuatu kenyataan bahwa, sekolah tidak merupakan sesuatu yang berdiri sendiri terpisah dari dunia luar, melainkan berada dalam suatu sistem masyarakat yang telah tetap.

Nasution (2010:97) menyatakan bahwa pelaksanaan kegiatan humas secara eksternal dilaksanakan dengan tujuan mempererat hubungan dengan masyarakat atau instansi di luar lembaga. Ketertarikan dunia usaha atau dunia industri terhadap sekolah dapat memberikan keuntungan, seperti halnya dalam referensi 
pelaksanaan prakerin. Selain sekolah, perusahaan juga mendapat keuntungan dengan adanya hubungan sekolah dengan dunia usaha, seperti mendapat sumber tenaga kerja dan memperluas promosi perusahaan kepada masyarakat luas. Berdasarkan fenomena tersebut, peneliti tertarik untuk meneliti:1) Perencanaan program humas dalam kemitraan di SMK Telkom Malang, 2) Pelaksanaan program humas dalam kemitraan di SMK Telkom Malang, 3) Evaluasi program humas dalam kemitraan di SMK Telkom Malang, dan 4) Kendala dan solusi dalam kemitraan di SMK Telkom Malang.

\section{METODE}

Penelitian ini menggunakan pendekatan kualitatif. Moleong (2012:6) menyatakan penelitian kualitatif adalahpenelitian yang bermaksud untuk memahami fenomena tentang apa yang dialami oleh subyek penelitian secara holistik dengan cara deskripsi, pada suatu konteks khusus yang alamiah dan dengan memanfaatkan berbagai metode ilmiah. Jenis penelitian yang digunakan dalam penelitian ini adalah studi kasus. Peneliti menggunakan jenis penelitian studi kasus, karena peneliti ingin menemukan dan mengetahui bagaimana manajemen program hubungan sekolah dan masyarakat dalam kemitraan di SMK Telkom Malang.

Kehadiran peneliti merupakan salah satu hal terpenting pada saat penelitian khususnya penelitian kualitatif. Peneliti datang langsung ke SMK Telkom untuk mendapatkan tanda-tanda yang terkait dengan penelitian yang dilakukan yaitu mengenai manajemen program hubungan sekolah dan masyarakat dalam kemitraan. Peneliti menemui stafhumas, peserta didik dan alumni untuk mendapatkan informasi yang terkait dengan fokus penelitian.

Lokasi penelitian adalah di SMK Telkom Malang yang beralamatkan di Jalan Danau Ranau Sawojajar Malang.Peneliti memilih lokasi ini dikarenakan program hubungan sekolah dan masyarakat sangat baik dan melibatkan alumni dalam kerjasamanya sehingga daya tarik dunia usaha terhadap sekolah ini sangat tinggi. Peneliti memperoleh data dengan melakukan wawancara secara langsung kepada beberapa informan untuk mengetahui manajemen program hubungan sekolah dan masyarakat dalam kemitraan di
SMK Telkom Malang. Selain itu peneliti juga melakukan pengamatan dan memperoleh data berupa dokumen dan foto-foto yang dapat mendukung hasil wawancara dan observasi yang dilakukan oleh peneliti.

Sumber data penelitian ini adalah staf bagian humas yaitu wakil kepala humas dan staf humas, peserta didik dan alumni.Teknik pengumpulan data yang digunakan dalam penelitian ini adalah wawancara, observasi, dan dokumentasi.Pengecekan keabsahan dilakukan untuk menghindari kesalahan data yang akan di analisis, dalam pengecekan keabsahan data peneliti menggunakan triangulasi, pengecekan anggota, perpanjangan waktu pengamatan, dan kecukupan bahan referensi.

Analisis data adalah proses menyusun data agar bisa ditafsirkan dan disimpulkan. Ulfatin (2013) menyitir pendapat Miles dan Huberman bahwa prosesanalisis data meliputi pengumpulan data, reduksi data, penyajian data, dan verifikasi data. Tahapan penelitian meliputi tahap pendahuluan yaitu peneliti melakukan observasi di SMK Telkom Malang. Observasi bertujuan agar peneliti mengetahui gambaran umum tentang lembaga, setelah itu peneliti menemukan hal yang menarik dan unik dari lembaga yang dijadikan fokus penelitian. Tahap penyusunan proposal bertujuan untuk memberikan gambaran secara umum tentang subyek penelitian dari hasil studi pendahuluan. Peneliti merancang proposal penelitian sebagai pedoman pelaksanaan penelitian guna mendapatkan hasil yang berkualitas. Tahap pelaksanaan dilakukan dengan menjaring data dan bukti dengan menggunakan metode yang dapat dipertanggungjawabkan secara ilmiah.Tahap penyusunan laporan dengan membuat laporan hasil penelitian yang dibuat secara deskriptif, naratif, obyektif, dan sistematis.

\section{HASIL}

Perencanaan program humas prakerin di SMK Telkom Malang melibatkan kepala sekolah, guru, staf, dan orang tua peserta didik, alumni, dan dunia usaha/dunia industri. Perencanaan prakerin dilakukan dengan kegiatan promosi dengan menggunakan media cetak, elektronik, dan lisan, kemudian sosialisasi, dan pembekalan. Pembekalan dilakukan secara internal dan eksternal. Pelaksanaan program humas prakerin 
dilakukan dalam kurun waktu tiga bulan. Setiap perusahaan mempunyai satu pamong dari sekolah dan satu pamong dari perusahaan. Pihak sekolah berkesempatan datang ke perusahaan selama proses prakerin untuk melihat secara langsung kinerja peserta didik dan upaya untuk menjalin hubungan baik dengan perusahaan.

Selanjutnya yaitu program humas wikusama festival (wikufest). Perencanaanprogram humas wikufest melibatkan guru, alumni, dan peserta didik, namun sebagian besar perencanaan wikufest yang terlibat yaitu alumni. Sebelum kegiatan panitia menyusun tema yang akan digunakan agar bisa menentukan pemateri yang akan diundang. Selain alumni juga ada panitia internal yang berasal dari guru dan beberapa siswa kelas sepuluh dilibatkan sebagai panitia teknis. Pelaksanaan wikufest dilakukan setiap satu tahun sekali. Kegiatan ini berupa seminar dua hari penuh yang berisikan tentang pengalaman kakak-kakak alumni di dunia kerja. Dengan adanya wikufest ini maka peserta didik lebih terbuka wawasannya untuk mengetahui dunia kerja.

Evaluasi dalam program humas berupa penilaian. Penilaian dalam program humas prakerin dimulai dari pembekalan, pelaksanaan, hingga penulisan laporan. Selain dari sekolah juga ada penilaian dari perusahaan. Sekolah memberikan formulir kepada perusahaan untuk penilaian peserta didik yang melaksanakan prakerin. Evaluasi dalam program humas wikufest yaitu rapat antara alumni dengan sekolah dalam program food gathering. Dalam kegiatannya mereka membahas tentang pelaksanaan wikufest dan segera mempublikasikan dokumentasi kegiatan ke dalam website, instagram dan facebook.

Kendala dalam pelaksanaan program humas yaitu susahnya mencari tempat tinggal atau kos untuk peserta didik sebelum melaksanakan prakerin di kota-kota besar. Hal ini dapat diatasi dengan cara pihak sekolah bekerjasama dengan satu koordinator industri, satu koordinator kota, orang tua peserta didik untuk mencari tempat tinggal atau kos. Kendala selanjutnya yaitu peserta didik sering tidak masuk atau membolos saat pelaksanaan prakerin, sekolah mempunyai cara dengan cara menggunakan media whatsapp sebagai cara komunikasi dengan peserta didik di perusahaan.

Kendala saat pelaksanaan program humas wikufest yaitu masalah cuaca. Karena ada beberapa kegiatan yang dilakukan di luar ruangan sehingga cuaca hujan menghambat kegiatan tersebut. Dengan ini panitia mengatur jadwal kegiatan outdoor pada pagi hari untuk mengurangi resiko jika terjadi hujan.

\section{PEMBAHASAN}

Sesuai dengan hasil penelitian bahwa program humas dalam kemitraan di SMK Telkom Malang ada dua yaitu prakerin dan wikufest. Perencanaan program humas di SMK Telkom bertujuan untuk menyusun program kerja yang akan dilaksanakan dalam kurun waktu satu tahun. Tanpa ada perencanaan yang matang maka program kerja tidak dapat berjalan dengan baik dan sesuai dengan tujuan yang direncanakan. Sesuai dengan pernyataan Usman (2010:66) perencanaan pada hakikatnya adalah proses pengambilan keputusan atas sejumlah alternatif (pilihan) mengenai sasaran dan cara-cara yang akan dilaksanakan di masa yang akan datang guna mencapai tujuan yang dikehendaki. Merencanakan program humas prakerin dilakukan dengan cara promosi terhadap dunia industri/dunia usaha, promosi dilakukan untuk marik minat dari industri. Sebagaimana pernyataan Rosyidi (2011) dalam hal mengembangkan kerjasama antara sekolah dengan industri, sekolah harus bersikap bahwa sekolah lebih berkepentingan, dengan sikap seperti ini, sekolah harus selalu mengambil inisiatif mendekati industri.

Promosi SMK Telkom menggunakan beberapa teknik seperti media cetak yaitu: brosur, baner, dan yellow page; dan teknik media elektronik seperti email, website;serta media sosial seperti facebook, twitter, whatsapp, dan instagram. Setelah promosi, kemudian dilakukan sosialisasi pada saat siswa kelas XI dan pembekalan pada saat peserta didik kelas XII.Promosi merupakan salah satu teknik dalam pemasaran jasa pendidikan. Benty dan Gunawan (2015) menjelaskan pemasaran jasa pendidikan bertujuan untuk: memberi informasi kepada masyarakat tentang produk sekolah, meningkatkan minat masyarakatpada produk sekolah, membedakan produk sekolah dengan sekolah lain, dan mensatabilkan eksistensi kebermanaan sekolah di masyarakat. 
Pelaksanaan program kerja praktik kerja industri(Prakerin) di SMK Telkom dilakukan saat siswa berada di kelas XII. Pelaksanaan prakerin di perusahaan dilakukan selama tiga bulan. Sedangkan pelaksanaan wikufest dilakukan setahun sekali. Sejalan dengan hal iniKurniadin dan Machali(2012:372-373)menjelaskan bahwa penilaian adalah suatu proses atau kegiatan yang sistematis dan berkesinambungan untuk mengumpulkan informasi tentang proses dan hasil belajar peserta didik dalam rangka membuat keputusan-keputusan berdasarkan kriteria dan pertimbangan tertentu. Evaluasi program humas prakerinmulai pra-prakerin, proses prakerin, hingga pelaporan dan evaluasi wikufest dilakukan saat kegiatan food gathering.

Kendala yang dihadapi sekolah dalam program humas prakerin yaitu susahnya mencari tempat tinggal untuk peserta didik di kota-kota besar namun pihak sekolah bisa menanganinya dengan cara bekerjasama dengan satu koordinator industri, satu koordinator kota, orang tua peserta didik untuk mencari tempat tinggal. Selanjutnya kendala mengenai lamanya balasan dari perusahaan, setelah peserta didik memilih lokasi prakerin pihak humas mengirim proposal kepada perusahaan dan beberapa perusahaan hingga tiga bulan tidak membalas dan akhirnya sekolah memilih untuk membatalkan mengirim peserta didik ke perusahaan tersebut. Kendala berikutnya yaitu sering peserta didik tidak masuk prakerin tanpa keterangan atau membolos, untuk mengatasi masalah ini sekolah memanfaat media elektronik berupa media sosial whatsapp untuk berkomunikasi dengan peserta didik yang berada di perusahaan.

Pemanfaatanmedia elektronik tersebut sesuai pendapat Nasution (2010:115-124) tentang media yang dapat digunakan dibagi menjadi dua jenis yaitu media internal dan media eksternal, media internal meliputi warta atau buletin, papan informasi, papan foto, spanduk dan baliho, kotak saran, presentasi video dan slide, stasiun radio sendiri, kaset video dan LCD, komunikasi tatap muka, acara kekeluargaan, klub sosial, literatur pengenalan/informasi, dan jaringan telepon internal. Sedangkan media eksternal meliputi jurnal eksternal, media audio visual, literatur edukatif, komunikasi lisan, pameran, seminar dan konferensi, sponsor, media cetak, media elektronik, mediat tatap muka, media cetak, spanduk dan umbul-umbul, profil lembaga, kegiatan khusus, dan media internet. Masalah pada pelaksanaan wikufest yaitu hujan yang menghambat kegiatan tersebut. Dengan ini panitia mengatur jadwal kegiatan outdoor pada pagi hari atau siang hari untuk mengurangi resiko jika terjadi hujan.

\section{KESIMPULAN DAN SARAN}

\section{Kesimpulan}

Perencanaan prakerin dilakukan dengan cara promosi, sosialisasi dan pembekalan. Pembekalan dilakukan dua kali yaitu secara internal dan eksternal. Sedangkan perencanaan wikufest dilakukan dengan cara membentuk panitia dan menentukan tema, penentuan tema dilakukan agar bisa menentukan narasumber yang akan diundang.

Pelaksanaan prakerin dilakukan saat peserta didik berada di kelas XII semester 1 , pelaksanaan prakerin dilakukan selama 3 bulan. Saat berada diperusahaan, pihak sekolah berkesempatan untuk mendatangi perusahaan untuk memantau peserta didik di perusahaan. Sedangkan pelaksanaan wikufest setahun sekali, bentuk kegiatan wikufest yaitu sharing keilmuan dengan alumni. Selain itu juga ada permainan edukasi.

Evaluasi prakerin dilakukan mulai praprakerin, pelaksanaan hingga penulisan laporan, sedangkan evaluasi kegiatan wikufest yaitu pertemuan antara sekolah dengan alumni pada acara food gathering untuk membahas kegiatan yang telah dilaksanakan.

Kendala yang dihadapi sekolah dalam program humas prakerin yaitu susahnya mencari tempat tinggal untuk peserta didik di kota-kota besar namun pihak sekolah bisa menanganinya dengan cara bekerjasama dengan satu koordinator industri, satu koordinator kota, orang tua peserta didik untuk mencari tempat tinggal. Selanjutnya kendala mengenai lamanya balasan dari perusahaan, setelah peserta didik memilih lokasi prakerin pihak humas mengirim proposal kepada perusahaan dan beberapa perusahaan hingga tiga bulan tidak membalas dan akhirnya sekolah memilih untuk membatalkan mengirim peserta didik ke perusahaan tersebut. Kendala berikutnya yaitu sering peserta didik tidak masuk prakerin tanpa keterangan atau membolos, untuk 
mengatasi masalah ini sekolah memanfaat media elektronik berupa media sosial whatsapp untuk berkomunikasi dengan peserta didik yang berada di perusahaan.

Sedangkan kendala dalam kegiatan wikufest yaitu masalah cuaca. Karena ada beberapa kegiatan yang dilakukan di luar ruangan sehingga cuaca hujan menghambat kegiatan tersebut. Dengan ini panitia mengatur jadwal kegiatan outdoor pada pagi hari untuk mengurangi resiko jika terjadi hujan.

\section{Saran}

Berdasarkan uraian tersebut, saran-saran yang diberikan sebagai berikut. Pertama kepada waka humas untuk lebih dapat meningkatkan pembinaan kepada semua anggota humas agar dapat melaksanakan tugasnya dengan baik. Kedua untuk staf humas diharapkan semua pengelola humas dapat menjalin komunikasi yang lebih baik dengan pihak internal dan eksternal lembaga. Ketiga untuk alumni agar semua alumni bisa mengikuti kegiatan wikusama festival dan bisa menjaga hubungan baik dengan sekolah dan dunia usaha/dunia industri. Keempat untuk peserta didik diharapkan peserta didik dapat mengikuti prosedur pelaksanaan prakerin dengan baik dengan cara mengikuti kegiatan sosialisasi dan pembekalan dan tidak melanggar peraturan yang dibuat saat pelaksanaan prakerin. Kelima untuk dunia usaha/dunia industri diharapkan dapat menjalin hubungan kerja sama yang baik dengan SMK Telkom Malang dan dapat mengembangkan kerja samanya dengan dunia pendidikan yang lain. Keenam untuk jurusan Administrasi Pendidikan dapat dijadikan sebagai bahan referensi dalam mengembangkan ilmu manajemen humas khususnya yang berkaitan dengan program humas dan yang terakhir untuk peneliti lain diharapkan dapat dijadikan inspirasi dan bahan referensi dalam mengembangkan ilmu pengetahuan dalam melakukan penelitian tentang manajemen program humas.

\section{DAFTAR RUJUKAN}

Anwar. 2006. Pendidikan Kecakapan Hidup (Life Skills Education). Bandung: Alfabeta.

Benty, D.D. \& Gunawan, I. 2015 Manajemen Hubungan Sekolah dengan Masyarakat: Malang: UM Press.

Daryanto, M. 2006. Administrasi Pendidikan. Jakarta: PT.Rineka Cipta.

Kurniadin, D \& Machali, I. 2012. Manajemen Pendidikan Konsep \& Prinsip Pengelolaan Pendidikan. Jogjakarta: Ar-Ruzz Media.

Kusumawati, D. 2015. Penggunaan Media Teknologi Informasi dalam Hubungan Industri di Sekolah Menengah Kejuruan. Jurnal Pendidikan, 24(6):540-546.

Prihatin, E. 2011. Manajemen Peserta Didik. Bandung: Alfabeta.

Moleong, L.J. 2006. Metodologi Penelitian Kualitatif. Edisi Revisi. Bandung: PT. Remaja Rosdakarya.

Nasution, Z. 2010. Manajemen Humas di Lembaga Pendidikan. Malang: UMM Press.

Rosyidi, E. 2011. Konsep Kerjasama Sekolah dan Industri. (Online), (http://www.edwardrosyidi. com/index.php?view $=$ article $\&$ catid $=3 \% 3 \mathrm{Aa}$ rtikel\&id=2\%3Akonsep-kerjasama-sekolahdan-industri-\&format=pdf\&option $=$ com content\&Itemid=2), diakses 17 Desember 2015 .

Ulfatin, N. 2013. Metode Penelitian Kualitatif di Bidang Pendidikan. Malang: Bayumedia Publishing.

Usman, H. 2010. Manajemen Teori, Praktik, dan Riset Pendidikan. Jakarta: Bumi Aksara.

Wiyono, B.B. 2010. Partisipasi Masyarakat Terhadap Pelaksanaan Kegiatan Pendidikan. Manajemen Pendidikan. 23(1): 1-11. 